\title{
THE MARTYR CULT OF THE FIRST WORLD WAR
}

by GAVIN WHITE

' $T \mathrm{~T}$ is certain that the unrest of Europe of the past twenty years will be dispelled. It is even likely that our whole civilisation will be advanced.' So wrote A. E. Lawrie, Rector of Old St Paul's Episcopal Church in Edinburgh, in October of 19I4. He was spending a three-month leave of absence as chaplain to an army hospital behind the lines in France. He added that the death of a particular soldier 'spoke so loudly of Another Cruel Death, that one could not but link the two together-the spirit of self-indulgence will be trodden underfoot and exchanged for the spirit of self-discipline."

Lawrie's expectation that the war would be over in three months proved mistaken, and by June I 915 he was an official chaplain to a brigade of English troops. And yet he was optimistic, for the troops were returning to religion. 'I'm afraid all the dreams of the Utopia of human progress and universal brotherhood with which the wonderful opening years of this twentieth century have been full are destined to meet with the same old awakening', he wrote, while 'such courage and self-forgetfulness as dignifies the Race must surely purify the nation.' As 1916 wore on he asked if it were not possible to return to 'Primitive Christianity', even while he grieved at the bodies laid out 'like so many dead rats' at the side of the road. But after the first two days of the Somme 'only about a fifth part of those to whom I had ministered for the last year were left', and Lawrie was never the same man again. ${ }^{3}$

But he still believed that some of the nobility of the trenches would be carried over into church life by disbanded soldiers. 'It is to the organised Church at Home that the men will turn for guidance ...' on social progress, and he asked, 'Why should the church not give that lead?' To his congregation he wrote in 1918 , 'It will be very difficult for you to see how great the impending social changes are.' And at the end of 1919 he wrote, "We are in the dawn of a new departure for the human race." But though he kept telling his people that he was going to reorder worship and

\footnotetext{
1 A. E. Lawrie, in Old St Paul's Magazine (Edinburgh, Oct. 19 I4).

2 Ibid. (March 1916).

${ }^{3}$ Ibid. (Aug. 1916).

4 Ibid. (Nov.-Dec. 1919).
} 


\section{GAVIN WHITE}

everything else to suit the disbanded soldiers, in fact, he made no changes. He went on as before, the Church went on as before, the country went on as before.

The martyr cult of the First World War was not widespread, but it was there. More widespread was a vague idea that if killing had to take place there must be some reason for it, and some benefit for those who had been left behind. This would make losses easier to bear, but it differed from the demand that blood should be deliberately shed to benefit the race. But there were varying degrees of acceptance of this ideal. Sir Alan Lascelles, a royal secretary in later life and a cavalryman in the war, wrote rather vaguely of martyrdom in a number of letters, most notably, 'God has a habit of giving Seydlitz powders to distempered nations from time to rime-they always come so appositely. Only this time he's given it to a hemisphere. I think the world would have been intolerable without the war....5 Yet he admitted that war had not brought spiritual blessings to him,

In the long-drawn torrure of an all-night trek; during the weary vigil at some rain-swept cross-roads, where rations were due at midnight and arrived at dawn-in all our squalid Gethsemanes, was our vision the Holy Ghost? Not mine. Mine was a crudely physical one, always the same-a white bed in a cloistered room without a clock. I thought a lot about God during the war; but it was in back-billets and clean linen. ${ }^{6}$

In one of the Anne of Green Gables books, there is a minister who greets the outbreak of war in 19I4 with the words, "Without shedding of blood there is no anything', and goes on to say, 'Our race has marked every step of its painful ascent with blood. And now torrents of it must flow again... it is the price humanity must pay for some blessing-some advance great enough to be worth the price ... .7 But if these words come from popular prose, most references to the blood sacrifice came from poets.

'Life springs from death, and from the graves of patrior men and women spring nations', ${ }^{8}$ orated Patrick Pearse at the grave of O'Donovan Rossa, and by I 9 is he was applying these thoughts to the rest of Europe.

3 Duff Hart-Davis, ed., End of an Era-Letters and Journals of Sir Alan Lascelles: from 1887101920 (London, 1986), p. 190.

6 Ibid., p. 267.

7 L. M. Montgomery, Rilla of Ingleside (London, 1983), p. 63.

8 Séan Farrell Moran, 'Patrick Pearse and the Politics of Redemption; the Mind of the Easter Rising $1910^{\circ}$ (The American University, Ph.D. thesis, 1989), p. 194. 


\section{Martyr Cult of the First World War}

'The old heart of the earth needed to be warmed by the red wine of the battlefields. Such august homage was never being offered to God as this, the homage of millions of lives given gladly for love of country.9 As one observer put it, Pearse demanded a 'blood sacrifice in every generation', 10 but in this he was not alone. Rupert Brooke never committed himself to the idea of the blood sacrifice, but he did write of the 'red sweet wine of youth', and, 'Now God be thanked who has matched us with His Hour, And caught our youth, and wakened us from sleeping.' At the very least this does bring in blood, and it holds that to die for one's country is not an unhappy duty, but, in his words, 'great fun', ${ }^{11}$ and life would have been empty without it. Charles Péguy was another who avoided the blood image, but his battlefield death in I9I4 was almost suicidal, and be constantly wrote of 'another age' to come, though to him the end of the world 'meant primarily that France and French culture would cease to exist. ${ }^{12}$ Yet that other age was to be won by sacrifice, and he was forever asking for regeneration through suffering. Of these three, Pearse, Brooke, and Péguy, it has been noted by Séan Farrell Moran that they all wrote in the early days of the war, and did not know the horrors of the trenches. Had they done so, they might have moderated their views, as did A. E. Lawrie.

Yet of these three, Pearse is the only one clearly teaching rebirth through the shedding of blood, and we must ask whether the apparently useless sacrifice of the Easter Rising would have been really useless had it not occurred in Ireland. Padraig O'Malley has argued that, 'Central to the myth on which the Irish state is built and to the prehistoric gestations of the Celtic ethos is the idea of heroic sacrifice. ${ }^{13}$ This is probably true, but Ireland is not unique in this, and O'Malley has also noted that in the decade leading to Bobby Sands's death by sacrifice in a hunger strike, there were over two hundred hunger strikes in fifty-two countries, with twenty-three deaths spread across ten countries. ${ }^{14}$ It was the era, not the country, that mattered most. As for Ireland, it may be that the cult of martyrdom was not particularly Irish, but Irish affairs came to a head just when the cult of martyrdom was widespread throughout the world. Use

Ibid., p. 201.

10 lbid., p. 2 I I.

$"$ M. R. Brooke, The Collected Poems of Rupert Brooke, with a Memoir (London, 1927), Pp. 5, 7.

12 Marjorie Villiers, Charles Péguy-a Study in Integrity (London, 1965), p. I97.

13 Padraig O'Malley, Biting at the Grave: The Irish Hunger Strikes and the Politics of Despair (Belfast, I 990$)$, p. 138.

14 lbid., p. 25 . 
of this cult in reference to the war in France may have prepared the Irish people, or enough of them, to apply it to the Easter Rising.

That cult of martyrdom was a spindly thing, restricted to young men of good family and poetic ambition. It could be said of all of them as it was of German devotees, "They were willing to sacrifice their lives because they believed that through fighting, killing, and dying they were contributing to the moral elevation of their country and the progress of humanity.'15 This was linked to a legend of 'a mutation of species'16 in that generation, and a legend arose in Britain that, 'Once upon a time, before the Great War, there lived a generation of young men of unusual abilities. Strong, brave, and beautiful, they combined great athletic prowess with deep classical learning. ${ }^{17}$ Only such a generation could offer a worthy sacrifice, and only such a generation could be called upon to do so. The blood of ordinary people was not worth much. These chosen ones were wanderers between two worlds, 'one dead, the other powerless to be born', as T. S. Eliot put it. ${ }^{18}$

Yet this cult could hardly survive the filth and horrors of the trenches, where the dead lay unburied for years. And it did not survive; what did survive was the idea that the returning servicemen, having learned to work for the common good in war, would do the same in peace. In this way the world would be a better place, not through those who died, but through those who survived. And instead of a literary elite of the strong and beautiful, there was the 'extraordinarily strong new feeling in the Army-the result of the comradeship bred by the life of hardship and horror in the trenches. It was a feeling that ignored all barriers of class, position or rank.'19 When it was all over, the dead were buried beneath identical headstones, and a new and equal society was to be born at home. 'I can see a million visions that are dancing overhead, Of the glory that is dawning where the sky is burning red, Of the Britain to be builded for the honour of the dead, For the army's marching home.' So wrote Woodbine Willie, who was on more solid ground here than when he wrore of 'Christ's fools', 'Who grinned in their agony sharing, The glorious madness of God.'20

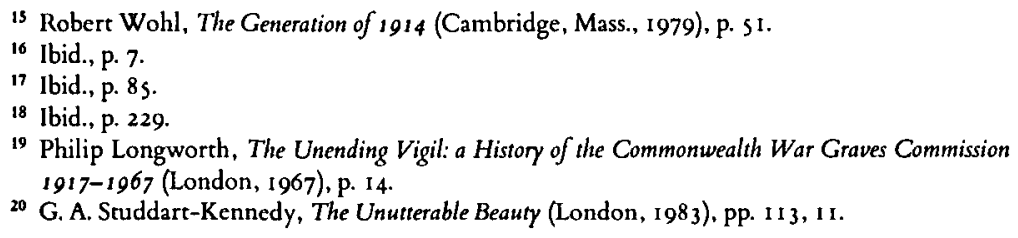




\section{Martyr Cult of the First World War}

But there are two major questions raised by all this. The first is how Christians, and all those quoted would have wished to be called such, could demand a blood sacrifice for the future of their people. Was the sacrifice of Christ on the Cross inadequate? Did its effect only last for so long? There is a troublesome verse in Colossians about making up what is lacking in Christ's sufferings, and if that can be explained away, the whole idea of following Christ in his sacrifice cannot. If his supreme work was sacrifice, and that was sufficient for all, why should his followers follow him? He had done it. But if this is one of those paradoxes which lie at the heart of all religion, it is normally met by keeping the two opposites in tension. On the one hand, accepting the benefits of Christ's sacrifice, and, on the other, following the moral example which he gave. These two approaches are, crudely put, the atonement theories of Anselm and Abelard. But in an age, and the beginning of this century was such an age, in which moral example was everything and benefits of sacrifice were almost nothing, sacrifice would not be highly regarded. It would then be natural for sacrifice to seep back into the system, and to do so in terms of a martyr cult in which Christ was followed by making a sacrifice which was as effective in its own realm as was his in heaven. Séan Farrell Moran has compared the Republican tradition in Ireland, in which violence is prescriptive, with Donatism, and even with the Taborites, in demanding more sacrifice than Christ gave. ${ }^{21}$ And it is probably true that any martyr cult is rooted in a theological inconsistency.

But this leaves the second question, and that is of blood. For us this is merely a useful fluid which carries nutrients around the body and disposes of waste. For our ancestors blood was special. It was the life-force of the body, and, in Antiquity, it was believed that human seed was a distillation of blood. ${ }^{22}$ Only in this way can Tertullian's remark about the blood of the martyrs being the seed of the Church make sense. Furthermore, the blood of the martyrs was shed on the soil, and this is close to Irenaeus' teaching of the first man being formed from the virgin earth. But it also reminds us, and would have more forcefully reminded those who lived at the start of the century, of blood and soil. Bringing those together was the act which led to new life.

How much of this lay in the minds of those young men who were supposedly endued with deep classical learning we may doubt. But something may have taken root in their minds. And there was another aspect of

21 Moran, 'Patrick Pearse', p. 265.

22 Aline Rousselle, Pomeia-On Desire and the Body in Antiquity (Oxford, 1989), p. I3. 


\section{GAVIN WHITE}

blood which was part of their lives; bleeding the sick to induce health. If this was done routinely for patients, and the use of leeches lingered on in British hospitals through the 1930s, could it not have been done for nations?

Yet behind all this hazy theory there were real people, such as A. E. Lawrie, who had returned to his Church, no longer expecting that a sacrifice would bring an automatic reward, and gradually realizing that in the hopes of a better life after the war, there would be no part for the Church to play. And, even more sadly, those hopes of a better life came to nothing. The blood was shed, but there was no new life.

University of Glasgow 